To Maega $\mid$ Jurnal Pengabdian Masyarakat

Februari 2021, Vol.4, No.1, hal, 47-54

$\operatorname{ISSN}(P): 2622-6332 ; \operatorname{ISSN}(E): 2622-6340$

http://www.ojs.unanda.ac.id/index.php/tomaega

\title{
Peran Kader dalam Mendorong Pemberian ASI di Masa Pandemi Covid-19
}

\author{
Adenia Dwi Ristanti 1 ${ }^{*}$, Elly Dwi Masita ${ }^{1}$ \\ ${ }^{1}$ Fakultas Keperawatan dan Kebidanan, Universitas Nahdlatul Ulama Surabaya \\ *Correspondent Email: adeniadr@unusa.ac.id
}

Article History:

Received: 20-10-2020; Received in Revised: 10-11-2020; Accepted: 16-11-2020

DOI: http://dx.doi.org/10.35914/tomaega.v4i1.474

\begin{abstract}
Abstrak
Coronavirus Disease 19 (COVID-19) merupakan penyakit yang disebabkan oleh Novel Coronavirus (2019-nCoV) atau yang kini dinamakan SARS-CoV-2 yang merupakan virus jenis baru yang belum pernah diidentifikasi sebelumnya pada manusia. COVID-19 telah dinyatakan sebagai pandemi dunia oleh WHO. Dalam kondisi pandemi COVID-19 ini, kader perlu melakukan upaya dalam penanganan, pencegahan serta pembatasan penularan infeksi salah satunya dengan mendorong ibu untuk tetap memberikan ASI di masa pandemi COVID-19. Pengetahuan kader dan ibu postpartum tentang pemberian ASI di masa pandemi COVID-19 berdasarkan pre test sebagian besar belum mengetahui, namun setelah dilakukan penyuluhan hasil post test hampir seluruh kader dan ibu postpartum sudah mengerti pemberian ASI di masa pandemi COVID-19. Diharapkan kader dan ibu hamil dapat ikut serta dalam program meningkatan pemberian ASI.
\end{abstract}

Kata Kunci: COVID-19, ASI, Kader

\section{Abstract}

Coronavirus Disease 19 (COVID-19) is a disease caused by the Novel Coronavirus (2019-nCoV) or what is now called SARS-CoV-2 which is a new type of virus that has never been previously identified in humans. COVID-19 has been declared a world pandemic by WHO. In the conditions of the COVID-19 pandemic, cadres need to make efforts in handling, preventing and limiting the transmission of infection, one of which is by encouraging mothers to continue to provide breast milk during the COVID-19 pandemic. Most of the cadres and postpartum mothers knew about breastfeeding during the COVID-19 pandemic based on pre-test, but after counseling on the results of the posttest, almost all cadres and postpartum mothers understood breastfeeding during the COVID-19 pandemic. It is hoped that cadres and pregnant women can participate in programs to increase breastfeeding

Key Word: COVID-19, Breasfeeding, Kader

\section{Pendahuluan}

Coronavirus Disease 19 (COVID-19) merupakan penyakit yang disebabkan oleh Novel Coronavirus (2019-nCoV) atau yang kini dinamakan SARS-CoV-2 yang merupakan virus jenis baru yang belum pernah diidentifikasi sebelumnya pada manusia. COVID-19 telah dinyatakan sebagai pandemi dunia oleh WHO (WHO, 2020)('Breastfeeding and COVID-19', 2020). Secara nasional melalui 
[ 48 ] Adenia Dwi Ristanti, dkk / To Maega : Jurnal Pengabdian Masyarakat, Vol.4; No.1; Februari 2021

Keputusan Kepala Badan Nasional Penanggulangan Bencana Nomor 9A Tahun 2020 yang diperbarui melalui Keputusan nomor 13 A Tahun 2020 telah ditetapkan Status Keadaan Tertentu Darurat Bencana Wabah Penyakit Akibat Virus Corona di Indonesia. Dalam kondisi pandemi COVID-19 ini, kader perlu melakukan upaya dalam penanganan, pencegahan serta pembatasan penularan infeksi salah satunya dengan mendorong ibu untuk tetap memberikan ASI di masa pandemi COVID-19.

Air susu ibu (ASI) adalah makanan terbaik bagi bayi karena mengandung zat gizi yang dibutuhkan bayi. ASI merupakan asupan gizi yang terbaik untuk melindungi dari infeksi saluran pernafasan, infeksi saluran pencernaan, alergi, obesitas juga membentuk perkembangan intelegensia dan perkembangan emosional. ASI mengandung kolostrum yang kaya akan antibodi karena mengandung protein untuk daya tahan tubuh, pemberian ASI eksklusif dapat mengurangi risiko kematian pada bayi (Giuliani et al., 2020). Kolostrum berwarna kekuningan dihasilkan pada hari pertama sampai hari ketiga. Hari keempat sampai hari kesepuluh ASI mengandung immunoglobulin, protein, dan laktosa lebih sedikit dibandingkan kolostrum tetapi lemak dan kalori lebih tinggi dengan warna susu lebih putih. Peran protektif ASI nampaknya konsekuensi dari tindakan sinergis dari berbagai macam komponen pendukung kesehatan seperti karbohidrat, imunoglobulin, nukleotida, lactoferrin, sitokin, sel kekebalan tubuh, asam lemak, lysozyme, dan faktor imunomodulator lainnya (Kohan and Rahnemaei, 2020).

World Health Organization (WHO), American Academy of Pediatrics (AAP), American Academy of Family Physicians (AAFP) dan Ikatan Dokter Anak Indonesia (IDAI) merekomendasikan pemberian ASI eksklusif selama 6 bulan dan dilanjutkan sampai 2 tahun. Melanjutkan menyusui lebih dari 6 bulan, disertai dengan makanan bergizi yang sesuai, cukup, aman, dan semi solid memadai, lembut, serta juga membantu memastikan status gizi yang baik dan melindungi terhadap penyakit (Salvatore et al., 2020).

Cakupan ASI Eksklusif di Indonesia pada tahun 2017 yaitu 55,7\% dan pada tahun 2018 mengalami penurunan menjadi 54,0\%. Cakupan ASI Eksklusif di Jawa Timur mengalami naik turun. Pada tahun 2017 yaitu 60,7\%, kemudian meningkat pada tahun 2018 yaitu sebesar $61,60 \%$ akan tetapi terjadi penurunan pada tahun 2019 yaitu 59,9\%. Berdasarkan hasil laporan puskesmas tahun 2019, pemberian ASI Ekslusif pada bayi 0-6 bulan yaitu $67,16 \%$, terjadi peningkatan dari tahun 2019 yaitu 64,69\% dan tahun 2018 sebanyak 64,68\%.

Program yang telah dilakukan oleh pemerintah untuk meningkatkan cakupan ASI eksklusif yaitu diantaranya menentapkan beberapa regulasi untuk mendukung pemberian ASI Eksklusif di Indonesia antara lain: Peraturan pemerintah (PP) nomor 33 tahun 2012 tentang pemberian ASI Eksklusif. Peraturan Walikota Semarang (Perwal) No. 7 Tanggal 16 Januari 2013 tentang Program Peningkatan Pemberian ASI Eksklusif di Kota Semarang. Sehingga hal 
[ 49] Adenia Dwi Ristanti, dkk / To Maega : Jurnal Pengabdian Masyarakat, Vol.4; No.1; Februari 2021

ini membuat sosialisasi mengenai ASI Eksklusif menjadi lebih gencar dilakukan oleh tenaga Kesehatan.

Sosialisasi dan kampanye tentang ASI eksklusif telah dilakukan oleh pemerintah dan lembaga swadaya, akan tetapi pemberian ASI Eksklusif masih kurang dari target yang ditetapkan yaitu $80 \%$. Alasan ibu tidak memberikan ASI eksklusif ada banyak faktor diantaranya adalah : faktor pengetahuan ibu yang kurang mengenai ASI eksklusif, faktor nutrisi ibu selama hamil dan menyusui, psikologis, fisiologis dan hormonal ibu yang mengakibatkan produksi ASI kurang (Goyal, Singh and Melana, 2020).

Faktor pelayanan kesehatan juga memiliki peran terhadap praktik pemberian ASI eksklusif dan kolostrum. Kurangnya edukasi yang dilakukan oleh tenaga kesehatan menjadikan ibu kurang memiliki pengetahuan yang baik mengenai ASI Eksklusif (Bick et al., 2020). Konseling laktasi dapat diberikan dan terjadi transfer pengetahuan tentang ASI eksklusif . Selain perlunya konseling laktasi pada masa nifas, penggunaan tanaman herbal untuk meningkatkan produksi ASI bisa diberikan sebagai asuhan komplementer yang dapat diberikan pada saat kunjungan nifas. Hal ini juga dapat memberikan edukasi kepada ibu nifas mengenai pemanfaatan tanaman herbal yang bersifat laktagagum yaitu untuk meningkatkan produksi ASI (Green et al., 2020).

\section{Metode}

\section{a. Pra kegiatan}

Metode pelaksanaan dalam program pengabdian masyarakat melalui daring seminar dan pelatihan pemberian ASI di masa pandemi COVID-19 di wilayah Desa Sebaung Kecamatan Gending pada tanggal 29 Mei 2020 melalui 2 tahap yaitu

1) Rapat startegi pelaksanaan

Rapat strategi pelaksanaan dipimpin oleh ketua pelaksana untuk membahas mengenai strategi serta perencanaan program pengabdian masyarakat yang akan dilaksanakan.

2) Persiapan sarana dan prasarana

\section{b. Pelaksanaan kegiatan}

Pelaksanaan kegiatan merupakan tahapan utama dari program pengabdian kepada masyarakat. Responden adalah kader dan ibu postpartum didesa Sebaung Kecamatan Gending. Untuk pendampingan kepada masyarakat dibagi 3 sesi kegiatan yaitu:

1) Pendataan kader dan ibu postpartum 
[50] Adenia Dwi Ristanti, dkk / To Maega : Jurnal Pengabdian Masyarakat, Vol.4; No.1; Februari 2021

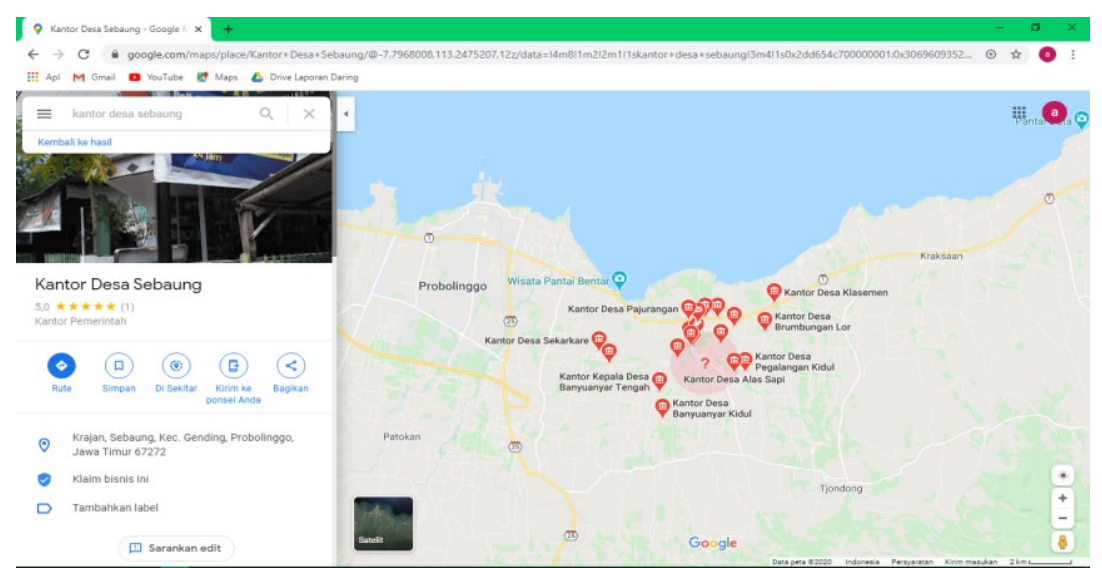

2) Penyuluhan pemberian ASI di masa pandemi COVID-19 secara daring melalui whatsApp dan door to door. Pemaparan materi disampaikan oleh ketua dan anggota pelaksana kegiatan pengabdian masyarakat dengan metode ceramah dan tanya jawab.
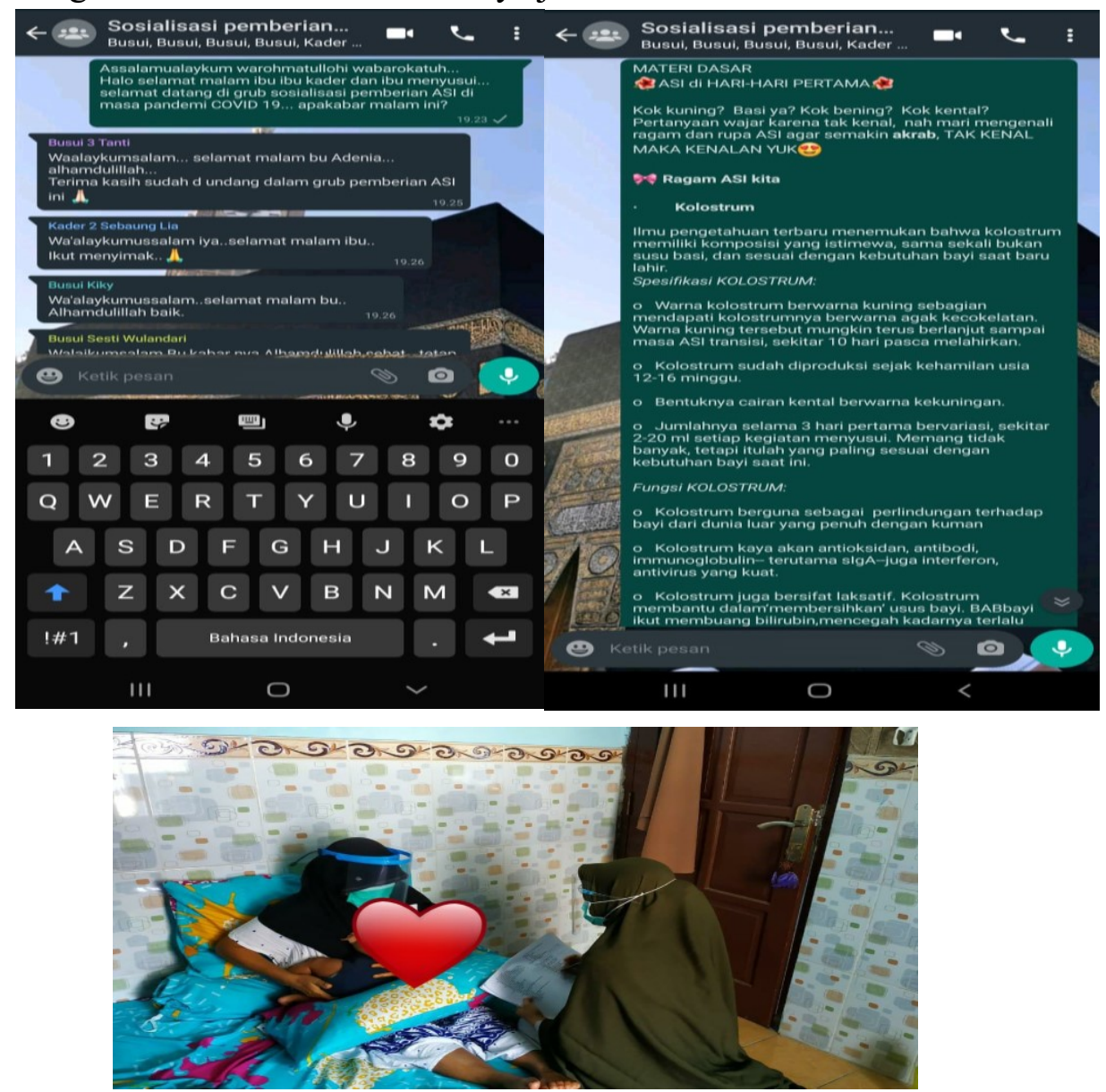

3) Pre test dan post test.

\section{c. Pasca kegiatan}

Tahap pasca kegiatan adalah tahap akhir dari program pengabdian masyarakat, pada tahap ini dilakukan evaluasi serta pembuatan laporan kegiatan. Evaluasi dilakukan sebelum dan sesudah kegiatan. 
[ 51] Adenia Dwi Ristanti, dkk / To Maega : Jurnal Pengabdian Masyarakat, Vol.4; No.1; Februari 2021

\section{Hasil dan Pembahasan}

Adapun hasil yang dicapai dari pelaksanaan kegiatan pengabdian masyarakat peran kader dalam mendorong pemberian asi di masa pandemi COVID-19 sebagai berikut:

a. Gambaran umum responden

Kegiatan pengabdian masyarakat ini dilaksanakan dalam bentuk penyuluhan tentang program peran kader dalam mendorong pemberian asi di masa pandemi COVID-19. Berikut merupakan gambaran umum responden yang seluruhnya berjenis kelamin perempuan.

Tabel 1. Distribusi peserta berdasarkan pendidikan

\begin{tabular}{clcc}
\hline No & Pendidikan & Jumlah & $\%$ \\
\hline 1 & Dasar & 5 & 29,4 \\
\hline 2 & Menengah & 10 & 58,8 \\
\hline 3 & Tinggi & 2 & 11,8 \\
\hline & Total & 17 & 100 \\
\hline
\end{tabular}

Berdasarkan tabel diatas, didapatkan informasi bahwa peserta sebagian besar berpendidikan menengah yaitu 58,8\%.

Pengetahuan merupakan informasi yang telah dikombinasikan dengan pemahaman dan potensi untuk menindaki yang lantas melekat di benak seseorang. Pada umumnya, pengetahuan memiliki kemampuan prediktif terhadap sesuatu sebagai hasil pengenalan atas suatu pola. Manakala informasi dan data sekadar berkemampuan untuk menginformasikan atau bahkan menimbulkan kebingungan, maka pengetahuan berkemampuan untuk mengarahkan tindakan. Pada kegiatan pengabdian masyarakat ini, para peserta diberikan penyuluhan berupa peningkatan peran kader dalam mendorong pemberian asi di masa pandemi COVID-19. Harapan dari penyuluhan ini yaitu para peserta dapat meningkatkan pengetahuan serta pemahaman mengenai program pemberian ASI sehingga dapat meningkatkan peran sertanya terhadap upaya peningkatan pemberian ASI dimasa pandemi COVID-19. Penilaian pengetahuan dari para peserta dilakukan dengan metode pre test dan post test.

Hasil dari pretest dan post test pengetahuan peran kader dalam mendorong pemberian asi di masa pandemi COVID-19 sebagai berikut:

Tabel 2. pre test dan post test peran kader dalam mendorong pemberian asi di masa pandemi COVID-19

\begin{tabular}{lccccccc}
\hline & \multicolumn{3}{c}{ Pre Test } & \multicolumn{3}{c}{ Post Test } \\
\hline & Tahu & \multicolumn{2}{c}{ Tidak Tahu } & & Tahu & \multicolumn{2}{c}{ Tidak Tahu } \\
\hline $\mathrm{N}$ & $\%$ & $\mathrm{~N}$ & $\%$ & $\mathrm{~N}$ & $\%$ & $\mathrm{~N}$ & $\%$ \\
\hline 3 & 17,6 & 14 & 82,4 & 16 & 94,1 & 1 & 5,9 \\
\hline
\end{tabular}

Berdasarkan tabel 2 diatas dapat dinyatakan bahwa hasil pre test 
[ 52 ] Adenia Dwi Ristanti, dkk / To Maega: Jurnal Pengabdian Masyarakat, Vol.4; No.1; Februari 2021

peserta yang mengetahui peran kader dalam mendorong pemberian asi di masa pandemi COVID-19 sebesar 3 orang (17,6\%), sedangkan berdasarkan hasil post test peserta yang mengetahui peran kader dalam mendorong pemberian asi di masa pandemi COVID-19 sebesar 16 orang $(94,1 \%)$.

Dilihat dari hasil pre test sebagian besar kader dan ibu postpartum belum mengetahui tetang peran kader dalam mendorong pemberian asi di masa pandemi COVID-19, namun setelah dilakukannya penyuluhan hasil post test hampir seluruh kader dan ibu postpartum sudah mengerti tentang peran kader dalam mendorong pemberian asi di masa pandemi COVID-19. Dapat disimpulkan bahwa terjadi peningkatan pengetahuan kader dan ibu postpartum sebab nilai post test lebih tinggi daripada nilai pre test.

ASI merupakan makanan lengkap yang dapat memenuhi kebutuhan zat gizi bayi yang baru lahir dan pada umur selanjutnya, apabila diberikan dalam jumlah yang cukup. ASI juga merupakan makanan terbaik dan sempurna untuk bayi, karena mengandung semua zat gizi sesuai kebutuhan untuk pertumbuhan dan perkembangan bayi (Wilson, 2020).

Setiap ibu yang melahirkan harus memberikan ASI Eksklusif kepada bayi yang dilahirkannya. Pola pemberian makanan terbaik untuk bayi sejak lahir sampai anak berumur 2 tahun meliputi: memberikan ASI kepada bayi segera dalam waktu 1 jam setelah lahir, memberikan hanya ASI saja sejak lahir sampai umur 6 bulan. Menyusui eksklusif selama 6 bulan menurunkan risiko infeksi akut seperti diare, pneumonia, meningitis, infeksi salarun kemih dan saluran pencernaan (Louis-Jacques and Stuebe, 2020).

Pemberian ASI membantu bayi memulai kehidupannya dengan baik. Kolostrum mengandung antibodi yang kuat untuk mencegah infeksi dan membuat bayi menjadi kuat. Penting sekali bagi bayi untuk segera minum ASI dalam jam pertama sesudah lahir, kemudian setidaknya setiap 2-3 jam. ASI mengandung campuran berbagai bahan makanan yang tepat bagi bayi. ASI mudah dicerna oleh bayi. Pemberian ASI secara Eksklusif yaitu pemberian ASI saja tanpa tambahan makanan lain pada bayi selama minimal 6 bulan dan bisa dilanjutkan sampai 2 tahun, setelah 6 bulan beberapa tambahan makanan lain harus ditambahkan pada bayi (Oras et al., 2020).

Bayi yang tidak diberikan ASI eksklusif selama minimal 6 bulan mengalami faktor resiko stunting pada usia 6-12 bulan 1,3 kali lebih besar dibandingkan bayi yang diberikan ASI eksklusif. Balita yang tidak diberikan ASI eksklusif selama 6 bulan memiliki resiko kejadian stunting 2,06 kali lebih besar dibandingkan yang diberikan ASI eksklusif. Fungsi ASI sebagai anti infeksi dapat mempengaruhi perubahan status stunting pada balita. Pemberian ASI eksklusif mengurangi tingkat kematian bayi 
[ 53] Adenia Dwi Ristanti, dkk / To Maega : Jurnal Pengabdian Masyarakat, Vol.4; No.1; Februari 2021

yang disebabkan berbagai penyakit yang umum menimpa anak-anak seperti diare dan radang paru. Hasil telaah dari 42 negara menunjukkan bahwa ASI eksklusif memiliki dampak terbesar terhadap penurunan angka kematian balita, yaitu 13\% dibanding perlakuan kesehatan masyarakat lainnya (Dalili et al., 2020).

b. Luaran yang dicapai

Luaran yang dicapai dari kegiatan pengabdian masyarakat tentang peran kader dalam mendorong pemberian asi di masa pandemi COVID-19 adalah sebagai berikut:

1) Peningkatan pemahaman serta kemauan kader dan ibu postpartum untuk ikut serta dalam peningkatan pemberian ASI.

2) Pemberian leaflet mengenai peningkatan kader dan ibu postpartum untuk ikut serta dalam peningkatan pemberian ASI.

\section{Kesimpulan}

Kegiatan pengabdian masyarakat dengan judul peran kader dalam mendorong pemberian asi di masa pandemi COVID-19 bertujuan untuk memberikan pengetahuan kader dan ibu postpartum tentang pemberian ASI di masa pandemi COVID-19 sehingga meningkatkan derajat kesehatan. Kesimpulan dalam pelaksanaan pengabdian masyarakat sebagai berikut: 1) kader dan ibu postpartum sebagian besar berpendidikan menengah, 2) pengetahuan kader dan ibu postpartum tentang pemberian ASI di masa pandemi COVID-19 berdasarkan pre test sebagian besar belum mengetahui, namun setelah dilakukan penyuluhan hasil post test hampir seluruh kader dan ibu postpartum sudah mengerti pemberian ASI di masa pandemi COVID-19. Diharapkan kader dan ibu hamil dapat ikut serta dalam program meningkatan pemberian ASI.

\section{Ucapan Terimakasih (Optional)}

Tim penulis mengucapkan terima kasih kepada LPPM Universitas Nahdlatul Ulama Surabaya yang telah mendanai pengabdian masyarakat ini.

\section{Daftar Pustaka}

Bick, D. et al. (2020) 'Maternal postnatal health during the COVID-19 pandemic: Vigilance is needed', Midwifery, 88, p. 102781. doi: https://doi.org/10.1016/j.midw.2020.102781.

'Breastfeeding and COVID-19' (2020) Bulletin de l'Académie Nationale de Médecine. doi: https://doi.org/10.1016/j.banm.2020.09.030.

Dalili, H. et al. (2020) 'Duration of Breastfeeding and Maternal-Related Factors in Iran, Systematic Review and Meta-Analysis', Journal of Pediatric Nursing, 54, pp. e23-e30. doi: https://doi.org/10.1016/j.pedn.2020.04.011.

Giuliani, C. et al. (2020) 'Breastfeeding during the COVID-19 pandemic: Suggestions on behalf of woman study group of AMD', Diabetes 
[ 54 ] Adenia Dwi Ristanti, dkk / To Maega : Jurnal Pengabdian Masyarakat, Vol.4; No.1; Februari 2021

Research and Clinical Practice, 165, p. 108239. doi: https://doi.org/10.1016/j.diabres.2020.108239.

Goyal, M., Singh, P. and Melana, N. (2020) 'Review of Care and management of pregnant women during COVID-19 pandemic', Taiwanese Journal of Obstetrics and Gynecology. doi: https://doi.org/10.1016/j.tjog.2020.09.001.

Green, J. et al. (2020) 'COVID-19 in babies: Knowledge for neonatal care', Journal of Neonatal Nursing, 26(5), pp. 239-246. doi: https://doi.org/10.1016/j.jnn.2020.06.005.

Kohan, S. and Rahnemaei, F. A. (2020) 'Delayed umbilical cord clamping and breastfeeding after childbirth in mothers affected by COVID 19: Recommended or not?', European Journal of Obstetrics \& Gynecology and Reproductive Biology, 250, p. 264. doi: https://doi.org/10.1016/j.ejogrb.2020.05.041.

Louis-Jacques, A. F. and Stuebe, A. M. (2020) 'Enabling Breastfeeding to Support Lifelong Health for Mother and Child', Obstetrics and Gynecology Clinics of North America, 47(3), pp. 363-381. doi: https://doi.org/10.1016/j.ogc.2020.04.001.

Oras, P. et al. (2020) 'A breastfeeding support program changed breastfeeding patterns but did not affect the mothers' self-efficacy in breastfeeding at two months', Early Human Development, 151, p. 105242. doi: https://doi.org/10.1016/j.earlhumdev.2020.105242.

Salvatore, C. M. et al. (2020) 'Neonatal management and outcomes during the COVID-19 pandemic: an observation cohort study', The Lancet Child \& Adolescent Health, 4(10), pp. 721-727. doi: https://doi.org/10.1016/S2352-4642(20)30235-2.

Wilson, J. C. (2020) 'Using Social Media for Breastfeeding Support', Nursing for Women's Health, 24(5), pp. 332-343. doi: https://doi.org/10.1016/j.nwh.2020.07.003. 